\title{
Corporate Social and Ecological Responsibility of Russian Coal Mining Companies
}

\author{
Nikita Ravochkin ${ }^{1, *}$,Vladimir Shchennikov ${ }^{2}$, and Vasiliy Syrov ${ }^{3}$ \\ ${ }^{1}$ Kemerovo State Agricultural Institute, 6500565 Markovtseva Street, Kemerovo, Russia \\ ${ }^{2}$ Kemerovo State University 6500006 Krasnaya Street, Kemerovo, Russia \\ ${ }^{3}$ National Research Tomsk State University, 634050, 36 Lenina prospect, Tomsk, Russia
}

\begin{abstract}
Based on the provisions of corporate social responsibility and taking into account the specifics of Russian mining enterprises, the authors attempt to understand theoretically the corporate social and environmental responsibility in this paper. The study shows that the essence of the principles of socially responsible behavior has ancient roots, while the consumer's attitude towards nature begins only in the era of modern times. The genesis, evolution and transformation of social responsibility in Western countries in the twentieth century are traced. The necessity of taking into account the national social and cultural specifics of the domestic economy is substantiated instead of blind copying of foreign management practices. The difference in the formation of corporate social responsibility (CSR) abroad and in Russia is shown. The list of facts and factors contributing to the formation of CSR in Russian realities is given. With regard to the coal industry enterprises inconsistencies have been identified. Their overcoming will allow the enterprises formulating strategies for corporate social and environmental responsibility. The advantages of social and environmental responsibility in comparison with the legal one are presented. In conclusion, the authors summed up the theoretical interpretation of the object claimed in the introduction.
\end{abstract}

\section{Introduction}

Uncontrolled expansion of a human being into the space of nature, which led to the global environmental problems, we associate with the proclaimed by F. Bacon imperative "Knowledge is power" [1]. Any statement can be understood differently, however, it was this phrase that was aimed at increasing man's power over nature. First of all, the use of nature was taking place in connection with the implementation of economic activities by economic agents. The main goal of the capitalists was to obtain the maximum profit without taking into account any ethical aspects of conducting entrepreneurial activity. Such consumerism, on the one hand, has opened to the mankind unlimited possibilities for the transformation and use of nature in its own interests, on the other, increased its negative impact on it. The industrial revolution led to a rapid economic growth and simultaneous degradation of the environment: the maximum speed and efficiency of the use of natural resources

\footnotetext{
*Corresponding author: nickravochkin@mail.ru
} 
caused a rapid destruction of the environment. Natural resources, which seemed unlimited, could not withstand their outstripping use by entrepreneurial structures.

At the turn of the XIX-XX centuries the tendencies that testify to the system and interdependence of the processes taking place in all spheres of public life intensified. For the first time, an emphasis is placed on the environmental consequences of capitalism. Beginning with the problems of individual industrial cities, the current economic, environmental and social contradictions have clearly regional and, more recently, global character, presenting one of the problems of our time. For example, meeting fast changing needs of the population in developed countries can lead to the simultaneous death of people in the Third World countries due to environmental pollution, poor medical care, food problems, etc. In other words, the problem of favorable living conditions for future generations is treated just as an ecological crisis.

In modern economy, the outlines of globalization are ever more clearly emerging, setting the single vector of development and unifying the standards of doing business. However, it is true that not all subjects of the market economy take effective measures to respond to the fact of ecological crisis. The authors attribute this mainly to the mental processes and the remaining intentions of profit maximization for the management of most companies and the unwillingness to take the responsibility for the consequences of their own activities.

Russian enterprises are the most vivid examples of so-called "irresponsible corporate behavior". The lagging behind of the domestic economy from the West is due, in our opinion, ideological isolationism, which contributed to the later realization and implementation of the world business standards. The Russian coal enterprises have been least adapted to socially responsible operations, as only the first of three interrelated components (economic, social, ecological) is taken into account. These companies are potentially dangerous for the environment. Domestic practice has shown that in the operations of these enterprises the most difficult is to make effective management decisions that determine their integration into the global economic environment. Impacting the environment, coal industry enterprises have a complex negative influence on it. The problem of this study is related to the fact that more than half of Russia's population lives in unfavorable environmental conditions. At the same time, their ignoring the consideration of the interests of society and sustainable development sets the urgency of the research and allows formulating its object. It is a theoretical comprehension and identification of the state of corporate social and environmental responsibility of Russian coal industry enterprises.

\section{Materials and Methods}

Having analyzed the possible irreversible consequences of the consumer attitude toward environment, the Western business came to the need to identify its own functions and role in the social development and interaction in the realities of the conflicting interests of various social actors. Initially, the boundaries of corporate social responsibility (CSR) were blurred and narrowed down a trivial abstract view: "Is it possible to maximize profits and make the world better?" G. Bowen [2] was the first who formulated the main provisions and directions of socially responsible activity of entrepreneurs. He pointed to the need for the business to participate in values and goals of the interested parties (stakeholders), the main of which were society and the state. It is curious that similar ideas of following the moral duty and free will that determined the responsibility of human behavior in this world could be found in the first philosophical teachings of Indian, Chinese and Greek thinkers. However, we observe that their introduction into the world business practice occurred much later - in the middle of the twentieth century. Within the framework of our research, we note that the first western socially responsible models of behavior of market economy sub- 
jects took into account the aggravation of social and economic and environmental problems.

Later, in the works of H.I. Ansoff [3], T. Donaldson [4], P. Drucker [5], Ph. Kotler [6], A. Carroll [7, 8], M. Porter [9], R. Freeman [10] and other researchers, there was the evolution and transformations of the concepts of CSR. Their essence lies in the expansion of the circle of stakeholders, the substantive concretization of their relations with them in the conditions of growing competition, the first systemic formulations of value expectations that contribute to social progress, social forecasting and response to the constant changes and requests for the world development. It should not be forgotten that the image of a socially responsible company is developed not only in the eyes of the public, but also in the minds of its own personnel. The future of the enterprise depends on the integrated accounting of the views of stakeholder groups. To do this, it is necessary to maximize benefits for all stakeholders (utilitarianism for the greatest number). Note that the Western CSR practice was also developed under the influence of the ideas of civil society.

The theoretical analysis of the works of the twentieth century revealed that, despite the recognition of universal responsibility, the main provisions of CSR only episodically describe the synthesis of environmental and social responsibility [11]. This indicates the need to take into account environmental values and factors that are now actively presented in the social reports of large industrial enterprises for which the greening of operations is mandatory. It is obvious that today the activities of industrial organizations should be programmed in accordance with economic, social and environmental aspects, giving a synergistic effect.

According to the author's opinion, corporate social and environmental responsibility is the sum of voluntary investments by enterprises to solve problems of social injustice and reduce tensions in society in order to avoid economic losses and to enhance the reputation effect.

\section{Results and discussion}

Russia, unlike the West, had no institutional foundations for CSR formation until the early 1990s. The main ideas of responsible business were borrowed from the most successful foreign companies, without taking into account the specifics of the actual Russian realities. Economic responsibility, i.e. the company's performance of its basic functions, traditionally was the only one for Soviet companies. Activities aimed at addressing social problems and the achievement of the public benefit, was practically absent [12, 13]. CSR in Russia was formed not under the influence of civil society structures and public policy, but in view of the following facts and factors:

- ambiguous attitude towards the results of privatization reform;

- lack of rational arguments regarding the origin of large capitals and the relationship between the increase in the value of companies and socially responsible strategy;

- uneven concentration of the capital of enterprises in the regions of the country (climatically unfavorable and undeveloped);

- the growing gap between the poor and the rich in the regions;

- mental features of the population of the country with simultaneous high level of expectations, pessimism and low level of social activity;

- traditionalism in the methods of management and practice of labor relations (double standards);

- the variety of social problems which multiplication is observed in the Russian society up to the present time.

It is therefore natural that today most large industrial enterprises for a number of reasons are in a transit from the socialist paternalistic views to the universal practice of CSR. It should be noted that a number of industries integrated into the global economy (usually 
dealing with the Western partners) are already successfully implementing a socially oriented business strategy, trying to take into account the interests and expectations of stakeholders.

Russian coal industry has long been considered a subsidized industry. Despite this, coal mining enterprises face a number of factors constraining the development of the industry. This can include technical, technological, economic factors, but the main ones, we believe, are managerial and environmental. The impact of this industry goes in a negative way, affecting the living standards of the population, its expectations and conditions of existence in general. There are ecological-and-economic and social-and-ecological contradictions, formed by the trajectory of the development of operations of the coal industry enterprise, which do not coincide with the values and even natural rights of the citizens.

The latter is very often observed in single-industry cities, as the relation of the coal mining enterprises to nature, like their organization, has not fundamentally changed for a long time. The coal mining enterprises in the settlements objectively worsen the living conditions. As a rule, the coal industry enterprises are organized in such a way that their personnel live in mining towns and villages in close to coal deposits or within the boundaries of mining fields. All this creates a number of environmental problems inherent only in the coal regions. These include increased standards for the permissible load of harmful substances on all layers of the biosphere, the need to extinguish burning rock dumps, the widespread communication of occupational chronic and acute diseases, problems with waste disposal, etc.

At the same time, the current environmental crisis in the Russian coal regions contributed to the first alarmist estimates by the local communities. Restructuring of the coal sector is one of the characteristic features of the promising development, since it directly points to the renewal and modernization of its organizational and production structures. The consideration of the environmental aspect of social responsibility in the coal industry presupposes a gradual reduction of external negative effects of the industry enterprises' operations in the synthesis with environmentalism and preventive measures that would reduce the burden on the environment.

The Russian practice of entrepreneurial activity of coal mining enterprises reveals a number of inconsistencies, which indicate that the strategies of social and environmental responsibility have not yet received wide circulation and there is a need for overcoming the "socialist" vision of entrepreneurial activity:

- the wide use of command methods that lead to unavailability for conscious and active initiatives;

- the absence of special structural units and a clear understanding of objectives and essence of social and environmental responsibility and the reluctance to implement social investments leads to the lack of motivation for the "responsible" activities and a dual attitude towards CSR concepts;

- relatively low level of "civic self-awareness" among management;

- single and forced nature of ongoing initiatives and lack of social reporting;

- inability to anticipate the expectations of stakeholders, guided by the Soviet standards of planning the enterprises' operations.

Nevertheless, it is obvious that social responsibility is not absent in the domestic coal industry. Modern age does not correspond to the realities of the USSR, and the established management paradigm is approaching its regular change and subsequent differentiation. The efficiency of the coal industry today is measured not only by making a profit, but also by its correlation with the environment. The management of enterprises is aware of the need to implement a strategy of social and environmental responsibility, focusing on those enterprises of the sector that belong to multinational and national holdings, and consequently - implement the principles of socially responsible behavior. In positive modality, it can 
be estimated that the development of corporate social and environmental strategies of coal mining enterprises does not indicate a simple transfer of Western practice to Russian conditions, but rather demonstrates the creation of their own methodology for taking into account the expectations of specific stakeholders.

The social and environmental responsibility of coal enterprises, unlike legal responsibility, is estimated by us as the most effective. First, it is connected with the voluntary response of enterprises to emerging contradictions. Secondly, social and environmental initiatives go beyond the current legislation on environmental protection. Thirdly, forwardlooking and conducting business according to the global environmental standards is assessed as a conscious activity, which meets the support in the eyes of stakeholders. Fourthly, the above-mentioned Russian environmental legislation is characterized by the lack of compliance, the absence of real measures to bring to responsibility and the weakness of social control.

The Russian enterprises of coal industry, unlike foreign ones, have not yet reached a balance at the level of "economy-society-ecology", since there are no clear ideas about what economic efficiency should be (especially guided by various technological and environmental standards of operation). In addition, there is a question of what is the fairness of the distribution of limited resources and the regularities of building up the reputation of the enterprise. Finding out points of positive interconnections with ambiguous economic, social and environmental aspects of the management strategy contributes to the achievement of synergies and sustainable business competitiveness in the short, medium and long term, opening up new horizons for social and environmental initiatives. In addition, for the public to understand these perspectives, it is necessary to observe the principle of openness of information about the company's activities. Foreign standards of non-financial reporting are universal, therefore, we will only point out those sections of the reporting by which the interested parties, taking into account the specifics of the coal industry, can give their assessment:

1) "Economy": general coal mining, business contacts.

2) "Social activity" in relation to the population, public, municipal and non-profit organizations and associations.

3) "Ecology": environmental information on the operations of the coal company.

As a theoretical core of the concept of corporate social and environmental responsibility, we proposed the synthesis of the social ecology laws of B. Commoner [14] with the generalization and systematization of data on the social and ecological problems of coal enterprises, the creation and implementation of social and environmental standards to modernized enterprises and technologies and the subsequent congruent development of technologies for the development and processing of deposits. Increasing utilization, transforming waste into useful forms, reducing energy costs, saving transportation costs, processing and disposal of garbage, improving product quality, environmental innovation - these are just some areas of the social and environmental responsibility of coal enterprises.

\section{Conclusion}

Every year Russian coal industry enterprises increase the degree of integration into the global economic processes, which makes them move along the path of increasing corporate transparency, social responsibility and efficiency. It is obvious that the introduction of the provisions of social and environmental responsibility in the Russian coal companies will become the norm of doing business in the near future. The permanent open dialogue with stakeholders and response to the social demands become the philosophy of the coal industry enterprises, helping them to determine and be informed about the true meanings and values of human existence, and the industry itself - to increase its competitiveness. 


\section{References}

1. F. Bacon, The New Organon (Cambridge University Press, Cambrige, 2000)

2. H.R. Bowen, Social Responsibilities of the Businessman (Harper and Row, London, 1953)

3. H.I. Ansoff, Strat. Man. J. 1:2, 131-148 (1980)

4. T. Donaldson, T.Dunfee, Ties that Bind: A Social Contracts Approach to Business Ethics (Harvard Business School, Boston, 1999)

5. P. Drucker, Innovation and Entrepreneurship (Harper, New York, 1985)

6. Ph. Kotler, N. Lee Corporate Social Responsibility - Doing the Most Good for Your Company and Your Cause (John Wiley and Sons, New Jersey, 2005)

7. A.B. Carroll, Bus. Soc. 28:3, 268- 295 (1999).

8. A.B. Carroll, Acad. Man. Rev. 4:4, 497-505 (1979)

9. M. Porter, M. Kramer, Harv. Bus. Rev. 80:12, 56-69 (2002)

10. R.E. Freeman, Calif. Man. Rev. 25:3, 88-106 (1983)

11. R. Barth, F. Wolff, Corporate Social Responsibility in Europe: Rhetoric and Realities (Edward Elgar Publishing, New York, 2009)

12. H. Söderbaum, Corporate Social Responsibility in Russia (Uppsala University, Helsinki, 2006)

13. M.S. Fifkaa, M. Pobizhan, J. Clean. Prod. 82, 192-201 https://doi.org/10.1016/j.jclepro.2014.06.091

14. B. Commoner, Making Peace With the Planet (Pantheon Books, New York, 1990) 